https://doi.org/10.30910/turkjans.448391

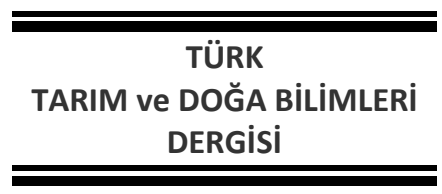

\title{
Asmada (Vitis vinifera L.) Klasik Melezleme Sonucu Elde Edilmiş F1 Genotiplerinin SSR Metodu ile Ebeveyn Tayini*
}

\author{
Atilla ÇAKIR ${ }^{1 *}$, Gökhan SÖYLEMEZOĞLU²
}

${ }^{1}$ Bingöl Üniversitesi, Ziraat Fakültesi, Bahçe Bitkileri Bölümü/BINGÖL

${ }^{2}$ Ankara Üniversitesi, Ziraat Fakültesi, Bahçe Bitkileri Bölümü/ANKARA

*Sorumlu yazar: cakiratilla@gmail.com

Geliş Tarihi: 27.03.2018

Düzeltme Geliş Tarihi: 10.07.2018

Kabul Tarihi: 18.07.2018

\section{Özet}

Araştırmada Karadimrit ve Boğazkere üzüm çeşitleri ana ebeveyn, 1103 P ve 140 Ru Amerikan asma anaçları da baba ebeveyn olarak kullanılmıştır. Melezleme sonucu elde edilmiş olan F1genotipleri bitkiye dönüşümü sağlandıktan sonra amaca yönelik olarak seçilmiş genotiplerde ebeveyn tayini yapılmıştır. Ebeveyn tayininde, Avrupa Birliği Araştırma Projesince (GENRES 081), Avrupa'daki asma çeşit koleksiyonları için kullanılan ve artık tüm dünya tarafından minimum standart set (core set) olarak kabul gören VVMD27, VrZAG79, VrZAG62. VVMD5, VVS2 ve VVMD7 mikrosatelik lokusları olmak üzere toplam 6 SSR primeri kullanılmıştır. Seçilen F1 genotiplerin (M1, M2, M3, M4) SSR lokuslarında ebeveynlere ait alleller olup olmadığı karşılaştırılmıştır. Karşılaştırma sonucunda F1 genotiplerinden yapılan karışımlardaki (M1, M2, M3, M4) SSR lokuslarında ebeveynlere ait alleller bulunmuştur. Elde edilen sonuçlar doğrultusunda yapılan melezleme çalışmasında doğru programın uygulanmış olduğunun ispatlanmış olması çok büyük önem arz etmektedir. Ayrıca bu alanda yapılmış ilk çalışmalardan biri olması da söz konusu çalışmanın önemini biraz daha ileriye götürmektedir. Klasik melezleme ile mokeküler biyoteknolojinin birlikte kullanılmış olması, bundan sonra yapılacak benzer çalışmalara ışık tutabilmesi umut edilmektedir.

Anahtar kelimeler: Vitis vinifera L., melezleme, F1, SSR.

\section{Parental Reassortment of F1 Genotypes Obtained in Asma (Vitis vinifera L.) Classical Hybridization Outcome by SSR Method}

\begin{abstract}
In the study, Karadimrit and Boğazkere grape cultivars were used as the maternal lines and 1103 P, 140 $\mathrm{Ru}$ American rootstocks as the paternal lines. After hybridization, the F1 genotypes obtained from the plant transformation were subjected to parental designation in selected genotypes for the purpose. In the Parental Assignment, European Union Research Project (GENRES 081), a total of 6, including VVMD27, VrZAG79, VrZAG62, VVMD5, VVS2 and VVMD7 microsatellite loci, which are now used as the minimum standard set by the whole world for the collection of grape varieties in Europe, SSR (simple sequence repeats)primer was used. The selected F1 genotypes (M1, M2, M3, M4) were compared in SSR loci whether they were parental alleles. As a result, parental alleles were found in SSR loci (M1, M2, M3, M4) in mixtures made from F1 genotypes. It is very important that the correct program has been proven to be applied in the cross-breeding study in the direction of the obtained results. Besides being one of the first studies made in this area, it takes the importance of studying a bit further. It is hoped that classical hybridization and molecular biotechnology can be used together to illuminate similar work to be done thereafter.
\end{abstract}

Key words: Vitis vinifera L., hybridization, F1, SSR. 


\section{Giriş}

Karadeniz ve Hazar denizi arasında bulunan ve Anadolu'nun Kuzeydoğu bölümünü de içine alan Kafkasya geçiş bölgesi (Transcaucasia), kültür (Vitis vinifera ssp. sativa) ve yabani (Vitis vinifera ssp. sylvestris) asmanın anavatanı ve kültüre alındığı yer olarak kabul edilmektedir (McGovern 2003). Bu nedenle Tükiye, kültür asmasının anavatanının sınırları içerisinde bulunmakta ve ülkemizin yaklaşık 6000 yıllık bir bağcılık kültürü ile çok zengin bir asma gen potansiyeline sahip olduğu bilinmektedir (Fidan 1985, Çelik vd. 1998, Ağaoğlu 1999).

$\mathrm{Bu}$ bulgulara ve asma gen potansiyelinin zenginliğine dayanan söz konusu hipotezler, yapılmış moleküler genetik çalışmalarla da kanıtlanmıştır. Anadolu'nun bağcılık kültürünün merkezlerinden biri olduğu, yabani asma popülasyonu çeşitliliğinin de en fazla bu bölgede bulunduğu, yaklaşık 10 ülkeden 1200 kültür çeşidi ve yabani asma üzerinde yürütülen SSR moleküler çalışmalar sonucunda belirlenmiştir (Arroyo-Garcia vd. 2006, Ergül vd. 2006).

Ticari öneme sahip diğer tüm bitkiler gibi çok yıllık kültür bitkileri içinde ıslah zor fakat kaçınılmaz bir konudur. Belirli seleksiyon ve/veya Islah yöntemlerinin doğru uygulanmasıyla; doğal seleksiyonla ortaya çıkmış bireylerin korunması, bunlardan daha üstün özellikleri taşıyanların ortaya çıkarılması veya istenilen özelliklerin bir bitkide toplanması mümkün olabilmektedir. Son çeyrek yüzyılda moleküler tekniklerin çok ileri düzeyde geliştirilerek bitki ıslahında kullanılmaya başlaması sonucunda asma ıslahı da daha bilinçli ve sistemli bir şekilde yapılmaya başlanmıştır. Zaman içinde daha bilinçli seleksiyon yapılması, mevcut üzüm çeşitlerinde verim artışı, kalitenin yükseltilmesi, çekirdeksizlik, yetiştirme alanlarının genişletilmesi, olum zamanlarının erkene veya daha geçe alınması, kuraklık-soğuk gibi anormal iklim koşullarına mukavemet, filoksera, nematod ve benzeri zararlılara, mantari hastalıklara, virüslere dayanıklılık, mekanizasyona uygunluk gibi konularda mevcut çeşitlerin ıslahına veya yeni çeşitler elde etmeyi amaçlayan ıslah çalışmalarına girişilmiştir (Fidan 1985, Ergül 1992).

Asmalarda hedeflenen amaçlara yönelik olarak gen haritasının çıkarılması üzerine yapılan çalışmaların sonuç vermeye başlamasıyla birlikte kromozom anormalliklerinden kaynaklanan pek çok kalıtımsal özelliğin öncelikli nedeni belirlenerek daha sonra da bu olumsuzlukların giderilmesi mümkün olabilecektir.

Özellikle yöresel çeşitlerin isimlendirilmesinde düzensizlikler ve benzer çeşitlere verilen farklı isimler bağcılıkta karışıklıklara sebep olmaktadır. Son yıllarda geliştirilen moleküler markörler yardımıyla ampelografik çalışmalara göre daha kesin sonuç veren yöntemler bağcılıkta yaygın bir kullanım alanı bulmuştur. Günümüze kadar yürütülen ampelografi çalışmalarına ilave olarak genetik düzeydeki çalışmalar, izoenzim düzeyinde tanımlama çalışmaları ile başlamıştır (Ağaoğlu vd., 1995; Ağaoğlu vd., 1998).

Morfolojik düzeyde yapılan tanımlamalara kıyasla izoenzimler farklılığı yakalamada daha iyi sonuç vermesine karşılık çevresel faktörlerden etkilenmeleri ve sayı azlığı gibi faktörlerden dolayı bazı dezavantajları da mevcuttur. Bu dezavantajlarından dolayı doğrudan karakterlerin orijini olan DNA'yı esas alan markörler geliştirilmiş ve bunlar kullanılmaya başlanmıştır.

Son yıllarda bağcılıkta kullanılan DNA markörler (RFLP, RAPD, AFLP, SSR ve ISSR vb.) değişik amaçlara yönelik yoğun kullanımları ile birlikte gerek bağcılıkta gerek diğer alanlardaki ıslah çalışmalarında bir çığır açmıştır. Bağcılıkta F1 tanısı başta olmak üzere farklı amaçlara (çeşit tanımlama, klonların sınıflandırılması, türler arası melezleme, gen aktarma, cinsiyet belirlenmesi, erken seleksiyon, genom haritalama, hastalıklara dayanım, hastalık ve zararlıların teşhisi vb.) yönelik olarak DNA marköler tek başına kombine bir şekilde araştırmalarda kullanılmaktadır (Ergül 2000).

Bu çalışmada ülkemizde yüksek kaliteli yerli üzüm çeşitlerinden olan Karadimrit ve Boğazkere üzüm çeşitleri ile kurağa ve kirece dayanıklı olan 140 $\mathrm{Ru}$ ve $1103 \mathrm{P}$ Amerikan asma anaçları kombinasyonu melezlerinin; asma çekirdeklerinin çimlenmesi, bitkiye dönüşüm oranları, elde edilen F1 genotiplerinin kuraklık, tuz ve polietilen glikol (PEG) uygulamalarına karşı dayanıklılıkları araştırılmıştır. Ayrıca, söz konusu kombinasyonlardan elde edilmiş olan F1 genotiplerinin SSR markörler yardımıyla "Melez Ebeveyn Tanısı" yapılmıştır.

\section{Materyal ve Yöntem Materyal}

Bu araştırma, 2007-2010 yılları arasında Tekirdağ Bağcılık Araştırma Enstitüsü, Antalya Aksu Perge Tarım Ürünleri San. ve Tic. Ltd. Şti. İşletmesi, fide üretim tesisi, Ankara Üniversitesi Ziraat Fakültesi Bahçe Bitkileri Bölümü ve Toprak Bilimi ve Bitki Besleme Bölümü üretim ve araştırma seraları ve Ankara Üniversitesi Biyoteknoloji Enstitüsü Laboratuvarı'nda yürütülmüştür.

Bitkisel materyal olarak; melezleme çalışmalarında Karadimrit ve Boğazkere üzüm çeşitleri ile tozlayıcı olarak kullanılan 140 Ru ve 1103 P Amerikan asma anaçlarına ait bitkiler, Gıda Tarım ve Hayvancılık Bakanlığı Tekirdağ Bağcılık Araştırma Enstitüsü Müdürlüğü'ndeki koleksiyon parsellerinde temin edilmiştir. 2007 ve 2008 vejetasyon dönemlerinde yapılan kastrasyon ve melezleme 
çalışmaları sonucu elde edilen meyvelerden alınan tohumlar Anatalya'da özel fide üretim tesislerinde bitkiye dönüştürülmüştür.

Melezleme sonucu elde edilmiş F1 genotipleri, Ankara Üniversitesi Ziraat Fakültesi Bahçe Bitkileri Bölümü üretim ve araştırma seralarında perlit:torf:cocopeat (1:1:1) karışımından hazırlanmış $11 \times 22 \mathrm{~cm}$ ebatında polietlen torbalara şaşırtılarak gelişimleri sağlanmıştır.

Denemeye alınmış genotipler daha sonra ebeveyn tayini için SSR reaksiyonlarına tabii tutulmuşlardır.

Denemede ebeveyn olarak kullanılan çeşitlere ait bazı özellikler aşağıdaki gibidir.

\section{Boğazkere üzüm çeşidi}

Ülkemizde Elazığ, Diyarbakır ve Malatya yörelerinde yaygın olarak yetiştirilen Boğazkere üzüm çeşidinin salkım şekli, kanatlı konik olup orta büyüklükte ve sık yapılıdır. Taneler mor-siyah renkte olup yuvarlak şekillidir. Orta büyüklükte (3-4 gr.) olan tanelerdeki çekirdek sayıları 2-3 adettir. Yüksek tanenli bir tada sahip olan Boğazkere, orta mevsimde olgunlaşmaktadır. Budama olarak yarı-uzun budama istemektedir (Anonim 1990b, Çelik 2006).

\section{Karadimrit üzüm çeşidi}

Ülkemizde İç Anadolu bölgesinde yaygın olarak yetiştirilen Dimrit (Sinonim: Dirmit) üzüm çeşidi, genelde şıralık (pekmez) ve şaraplık olarak yetiştirilen bir çeşittir. Karadimrit üzüm çeşidi aynı zamanda kurutmalık olarak da kısmen değerlendirilmektedir (Anonim 1990b, Ağaoğlu 1999, Anonim 2007).

Karadimrit üzüm çeşidi, kırmızımsı mor, hafif oval, küçük, 1-2 adet çekirdek içeren tanelere sahip olan bu çeşit, salkımları kanatlı silindirik formda olup, orta büyüklükte ve oldukça sık salkımlıdır. Orta mevsimde olgunlaşır ve kısa budama istemektedir. Karadimrit üzüm çeşidi kurutmalık olarak değerlendirilen üzüm çeşitleri içerisinde yer almaktadır (Aras 2006).

Elde edilen F1 genotip ebeveyn tayini çalışmasında ana ebeveyn olarak kullanılan çeşit, kurutmalık olarak da kullanılabilen Karadimrit üzüm çeşididir.

\section{P Amerikan asma anacı}

11103 P Amerikan asma anacl, Vitis berlandieri x Vitis rupestris melezidir.

Sürgün ve sürgün ucu örümcek ağı gibi tüylüdür. Genç yapraklar tüysüz bronz rengindedir. Olgun yapraklar böbrek şekilli olup sap cebi U şeklindedir. Kuvvetli gelişen bu anaç aktif kirece \% 17-18 oranında dayanır. $0.6 \mathrm{~g} / \mathrm{kg}$ tuza dayanıklıdır. Aşı tutma ve köklenme oranı oldukça yüksektir (Adams 1979, Çelik 1998, Çelik 2006).

\section{Ru Amerikan asma anacı}

$140 \mathrm{Ru}$ Amerikan asma anacl, Vitis berlandieri x Vitis rupestris melezidir.

Sürgün ucu örümcek ağı gibi tüylü ve kenarları açık kırmızı renklidir. Genç yapraklar donuk, yeşil ve parlaktır. Olgun yapraklar küçük ve böbrek şekillidir. Sap cebi açık U şekillidir. Sürgünler çizgili, hafif tüylüdür. Kuvvetli bir anaç olan $140 \mathrm{Ru}$, kurak ve kireçli topraklarda başarılı bir şekilde kullanılmaktadır. Topraktaki aktif kirece dayanımı \% 20 civarında olup, filokseraya dayanımı iyidir. Çelikleri zor köklenir. Aşı tutma oranı düşüktür. Bağdaki aşılamalarda aşı tutma oranı yüksektir (Adams 1979, Çelik 1998, Çelik 2006).

\section{Yöntem}

2007-2011 yılları arasında yürütülen çalışma sonucunda elde edilmiş F1 genotiplerine ait tiplerde SSR reaksiyonları gerçekleştirilmiştir.

\section{SSR}

Mikrosatellitler aracılığıyla hibritlere ait melezleme kombinasyonunun SSR markörlerle tanımlanması temelde dört aşamadan oluşmaktadır. Güvenilir ve sağlıklı datanın oluşturulabilmesi açısından her aşama üzerinde büyük bir özen ile durulması gerekmektedir. Sağlıklı data analizinde dikkat edilmesi gereken aşamalar şekilde sıralanabilir;

a) DNA izolasyonu.

b) SSR allel gölgelerinin PCR aracılığıyla çoğaltılması.

c) PCR ürünlerinin kapillar elektroforezi ve allel verilerinin görüntülenmesi.

d) Genetik analizler.

\section{DNA izolasyonu}

Lefort vd. (1998) metoduna göre DNA izolasyonu sürgün ucu ve genç yapraklardan elde edilmiştir. Her bir genotip örneğine ait 3 DNA ölçümü gerçekleştirilirken, DNA saflık ve miktarlarını tespit etmek amacı ile \%1'lik agaroz jel ve Nanodrop ND-1000 spektrofotometre kullanılmıştır. Çalışmada kullanılan uygun DNA izolasyon yöntemi aşağıdaki gibi gerçekleştirilmiştir.

F1'lere ait sürgün ucu ve genç yapraklar havana konulup sıvı azotla iyice ezilmiştir. Sıvı azotta iyice ezilmiş olan genotiplere ait örneklerden 100 mg alınarak $2 \mu$ lependorf tüpe aktarılmıştır. Ependorf tüplere aktarılmış örnekler üzerine, $1 \mathrm{ml}$ DNA ekstrasiyon solüsyonu (örnek başına $10 \mu \mathrm{l}$ 2Merkaptoethanol içerir) eklenmiş ve homojen hale gelinceye kadar karışması sağlanmıştır. Karışımları sağlanmış örnekler, içerisinde bulunduğu tüpler, sıcak su banyosunda $\left(65^{\circ} \mathrm{C}\right) 15$ dakika bekletilmiştir. ilgili ependorf tüplere $0.5 \mathrm{ml}$ kloroform/isoamil alkol 
(24:1) karışımı eklenerek iyice karışması sağlandıktan sonra 30 dakika buz üzerinde bekletilmiştir. Söz konusu örnekler $14.000 \mathrm{rpm}$ hızında 5 dakika santrifüj edilmiştir. Santrifüj işleminden sonra ependorf tüplerin üst kısmındaki sıvılar yeni tüplere aktarılmıştır. Tüpler içerisinde kalan kısımların üzerine $0.8 \mathrm{ml}$ soğuk isopropanal eklenmiştir. İsoproppanal eklenmiş örnekler bir gece $-20^{\circ} \mathrm{C}^{\prime} \mathrm{de}$ bekletildikten sonra 1 dakika 14.000 rpm hızında santrifüj edilmiştir. Satrifüj işleminden sonra tüplerin içinde bulunan üst kısımdaki sıvı uzaklaştırılarak, alt katı (pellet) \%70'lik ethanol ile yıkanmıştır. DNA, 50$100 \mu \mathrm{l} \mathrm{H} \mathrm{O}^{\prime}$ da (nuclease free) çözülerek üzerine, her $100 \mu$ l solüsyon için $1 \mu \mathrm{l}$ RNase-A eklenerek, $37^{\circ} \mathrm{C}^{\prime}$ de 15 dakika bekletilmiştir.

\section{SSR allel bölgelerinin PCR aracılığıyla çoğaltılması}

PVR optimizasyon çalışmaları yapılarak, DNA çoğaltımı için Biometra ve MJ Research Thermocycler cihazı kullanılmıştır. PCR'da kullanılan reaktifler; 15-200 ng DNA, 5 pmol ileri (forward) primer, 5 pmol floresan işaretlenmiş ters (revers) primer, 0,5 mM toplam dNTP, 0.5 unit Go Taq DNA Polymerase (Promega) (1.5 mM MgCl 2 içermekte), 1 $\mu$ l buffer 10 x buffer olacak şekilde toplam $10 \mu \mathrm{l}$ PCR karışımı hazırlanmıştır.

\section{DNA çoğaltımı için kullanılan PCR programı;}

Illkönce $94^{\circ} \mathrm{C}$ de $3 \mathrm{dk}$. (1 döngü), daha sonra $94^{\circ} \mathrm{C}$ de 1 dakika uygulama gerçekleştirilmiştir. 48$66^{\circ} \mathrm{C}$ de 1 dakika (Primerin bağlanma derecesine bağı olarak değişmektedir). Bekletilen örnekler önce $72^{\circ} \mathrm{C}$ de 2 dakika, sonrasında da $72^{\circ} \mathrm{C}$ de 10 dakika (1 döngü) bekletilmiştir. $4^{\circ} \mathrm{C}$ de sabit tutulmuş örneklere en son olarak 2 . ve 4 . basamaklar toplamda 35 döngü olacak şekilde uygulanarak PCR programı tamamlanmıştır.

\section{Araştırmada kullanılmış SSR primerleri}

Araştırmada, Avrupa Birliği Araştırma Projesince (GENRES 081), asma çeşit koleksiyonları için kullanılan ve artık tüm dünya tarafından minimum standart set (core set) olarak kabul gören VVMD27, VrZAG79, VrZAG62. VVMD5, VVS2, ve VVMD7 mikrosatelik lokusları olmak üzere toplam 6 SSR primeri kullanılmıştır. Her lokusa ait ileri (forward) primer D4 (mavi), D3 (yeşil) ve D2 (siyah) renklerde floresan işaretlenmiş olup primerlere ait baz dizileri, kullanılan floresan boya ve $\operatorname{Tm}\left({ }^{\circ} \mathrm{C}\right)$ değerleri Çizelge 1'de verilmiştir (Thomas ve Scott, 1993; Bowers vd., 1996; Lefort vd., 1998; Sefc vd., 1999).

Çizelge 1. Kullanılan primerlere ait bilgiler.

\begin{tabular}{|c|c|c|c|c|}
\hline Sira & Lokus adı & Primer dizileri $\left(5^{\prime} . . .3^{\prime}\right)$ & İşaretleme boyası & $\mathrm{Tm}$ \\
\hline 1 & $\begin{array}{l}\text { VVS2F** } \\
\text { VVS2-R }\end{array}$ & $\begin{array}{c}\text { cagcccgtaaatgtatccatc } \\
\text { aaattcaaaattctaattcaactgg }\end{array}$ & D4 (Mavi) & 55 \\
\hline 2 & $\begin{array}{l}\text { VVMD5F** } \\
\text { VVMD5-R }\end{array}$ & $\begin{array}{l}\text { ctagagctacgccaatccaa } \\
\text { tataccaaaaatcatattccaa }\end{array}$ & D2 (Siyah) & 55 \\
\hline 3 & $\begin{array}{l}\text { VVMD7F** } \\
\text { VVMD7-R }\end{array}$ & $\begin{array}{l}\text { agattgcggagaacaggt } \\
\text { cgaaccttcacacgcttgat }\end{array}$ & D3 (Yeşil) & 55 \\
\hline 4 & $\begin{array}{l}\text { VVMD27F** } \\
\text { VVMD27-R }\end{array}$ & $\begin{array}{l}\text { gtaccagatctgaatacatccgtaat } \\
\text { acgggtatagagcaaacggtgt }\end{array}$ & D2 (Siyah) & 55 \\
\hline 5 & $\begin{array}{l}\text { VrZAG62F** } \\
\text { VrZAG62-R }\end{array}$ & $\begin{array}{l}\text { ggtgaaatgggcaccgaacacacgc } \\
\text { ccatgtctctcctcagcttctcagc }\end{array}$ & D4 (Mavi) & 66 \\
\hline 6 & $\begin{array}{l}\text { VrZAG79F** } \\
\text { VrZAG79-R }\end{array}$ & $\begin{array}{l}\text { agattgtggaggagggaacaaaccg } \\
\text { tgccccattttcaaavtvvvttccg }\end{array}$ & D3 (Yeşil) & 66 \\
\hline
\end{tabular}

\section{Kapiller elektroforez ve allel verilerin görüntülenmesi}

SSR allellerinin görüntülenmesi ve ayrımında kullanılan kapiller eletroforez yöntemi; jellere göre daha iyi ayırım gücü, zaman ve iş gücünden tasarruf, az miktar PCR ürünü kullanma, çok sayıda örnekle çalışabilmeye olanak sağlaması, DNA polimeraz'dan kaynaklanan ve starter pikler (bant) olarak adlandırılan PCR amplifikasyonu sırasında yanlış bağlanımların kolaylıkla belirlenmesi, otomatik olarak allel büyüklüklerinin tespit edilmesi ve yanlış okumaların ortadan kaldırılması gibi önemli avantajlara sahiptir. Söz konusu avantajlara sahip sistemlerin kullanıldığı metot kısmında kapiller elektroforez amaciyla Beckman CEQ $^{\mathrm{TM}} 8800$ ve
CEQ $^{\text {TM }} 8000$ Genetik Analiz Sistemi kullanılmıştır. Lokuslara ait PCR ürünleri \% 2'lik agaroz jelde koşturulduktan sonra, işaretlemede kullanılan floresan (Proligo, Wellred işaretli primerler, Fransa) boyalara göre (D4, D3, D2) örnekler değişik oranlarda (1:5, 1:10 gibi) $20 \mu \mathrm{l}$ SLS (Simple Loading Solution) ile seyreltilmiştir. Örnek ve SLS karışımları üzerine $0,4 \mu \mathrm{l}$ size standart-400 eklendikten sonra karışım vortekslenerek karıştırılmış sonra santrifüj edilerek üzerine bir damla mineral yağ damlatılmıştır. Daha sonra plate $\mathrm{CEQ}^{\mathrm{TM}} 8000$ Genetik Analiz Sistemi'nde elektroforez edilmiştir.

Araştırmada ana ve baba ebeveynler referans çeşit olarak kullanılırken, verilerin 
doğruluğundan emin olmak için reaksiyonlar en az iki kez tekrar edilmiştir.

Elektroforez sonunda her bir lokusa ait pikler, tipleri ve renkleri göz önüne alınarak heterezigot ve homozigot olarak görüntülenmiştir.
SSR kapillar elektroforez yönteminde uygulama aşamalarının genel görünümü Şekil 1'de gösterilmiştir.

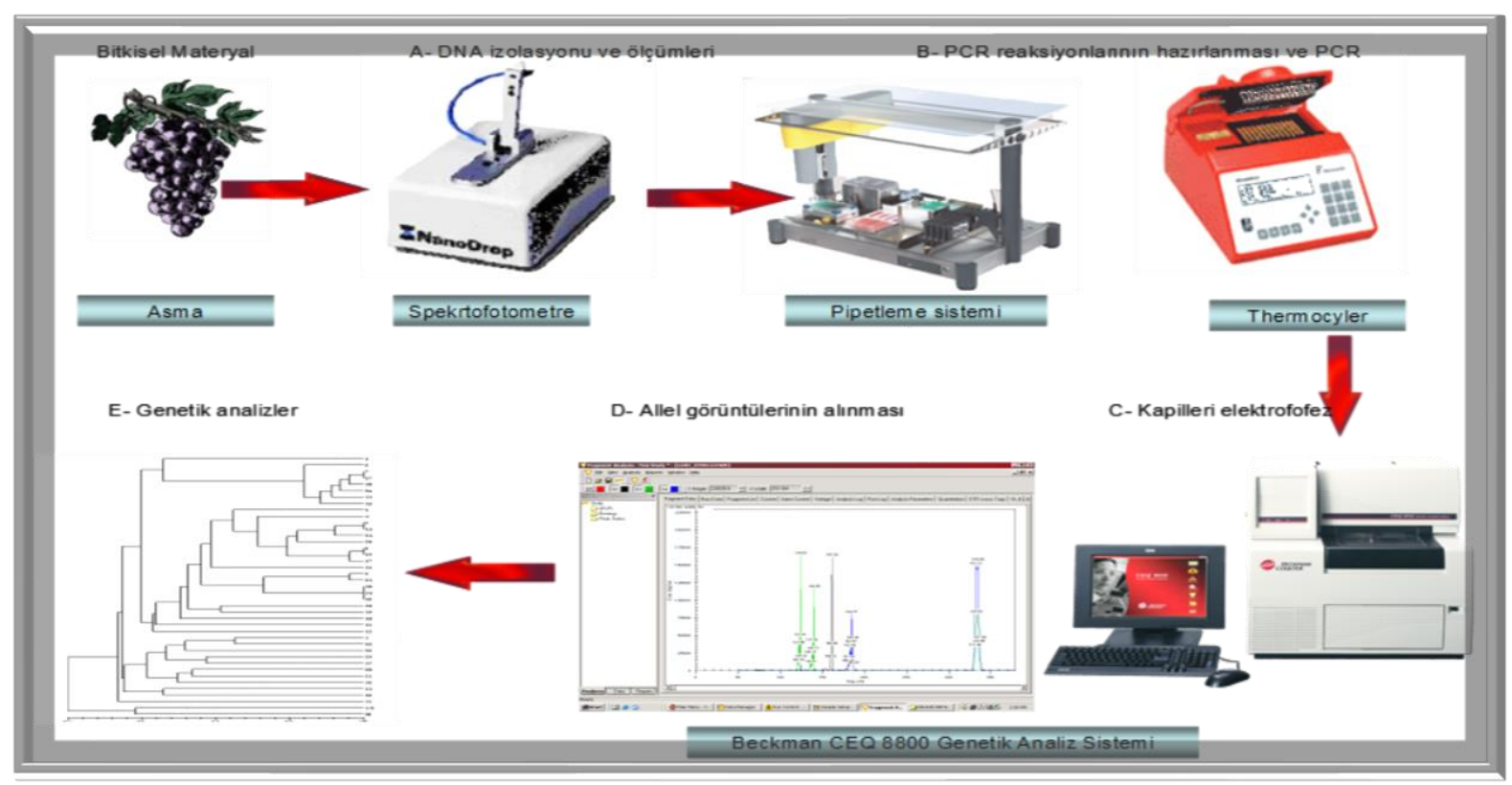

Şekil 1. SSR kapillar elektroforez yönteminde uygulama aşamaları.

\section{Sonuçların değerlendirilmesi}

Kapiller

elektroforez

yazılım

programlarından elde edilen ham verilerden ana, baba ve $F_{1}$ bitkilerinde allel büyüklükleri karşılaştırılmıştır.

\section{Genetik analizler}

Çalışmada genetik parametreler olarak; beklenen $\left(\mathrm{H}_{\mathrm{e}}\right)$ ve gözlenen heterozigotluk $\left(\mathrm{H}_{\mathrm{o}}\right)$, allel frekansı, allel sayısı (n), tahmin edilen sessiz allel (null) frekansı ( $r$ ) ve tespit olasılığı (PI, Probably of Identity) değerleri belirlenmiştir.

Beklenen heterezigotluk $1-\sum \mathrm{pi}^{2}$ şeklinde hesaplanmış ve buna göre genetik farklılık tespiti yapılmıştır. Formüldeki pi değeri, çalışılan örnekteki “i." allelinin frekansını göstermektedir (Nei 1987).

Gözlenen heterezigotluk ise, heterezigot genotiplerle analiz edilen toplam genotip arasındaki orandır. Null allel varlığının tahmini $(\mathrm{He}-\mathrm{Ho}) /(1+\mathrm{He})$ şeklinde hesaplanmıştır (Brookfield 1996). Tespit olasılığı (PI) (Paetkau vd. 1995) iki rastgele seçilmiş bireyin aynı SSR profiline sahip olma olasılığını ifade etmektedir.

Söz konusu bu değer, $\sum \mathrm{pi}^{4}+\sum \Sigma(2 \mathrm{pipj})^{2}$ şeklinde hesaplanmaktadır. Burada pi ve pj, sırasıyla "i" ve "j" allellerin frekansını göstermekte olup, daha sonra benzerlik indeksleri belirlenerek, genetik ilişki dendogramı oluşturulmuştur.
Çalışmada incelenmiş parametrelere göre kullanılan programları aşağıdaki şekilde sıralamak mümkündür:

Genetik paramatreler: Her lokusa ait allel frekansı, allel sayısı, beklenen ve gözlenen heterezigotluk oranı, sessiz (null) allel frekansı ve tespit olasılığı (PI) IDENTITY 1.0 programı ile (Wegner ve Sefc 1999) tespit edilmiştir.

Benzerlik oranı indeksi: Microsat programı ile (Minch vd., 1995) yapılmıştır.

Dendogram: UPGMA (Unweighted PairGroup Method using Arithmetic means) yöntemi kullanılarak NTSYS (Versiyon 2.02 g, Exeter Software, Setauket, NY) programı ile belirlenmiştir.

\section{Bulgular ve Tartışma}

F1 genotiplerin (M1, M2, M3, M4) SSR lokuslarında ebeveyne/ebeveynlere ait alleller olup olmadığı karşılaştırılmıştır. F1 bireylerinden yapılan karışımlardaki (M1, M2, M3, M4) SSR lokuslarında ebeveyne/ebeveynlere ait alleller bulunmuştur (Çizelge 2).

Ebeveynler ve F1'ler lokuslar bazında incelendiğinde, gerek $M 1$ ve $M 2$, gerekse $M 3$ ve $M 4$ genotipleri anne ve babadan ortak allellere sahip olmakla birlikte, ebeveynlerde bulunmayan allellere de sahip oldukları görülmüştür. Bu alleller M1 genotipinde VVMD27 lokusunda 179 alleli, M2 genotipinde VVMD5 lokusunda 229 alleli, VVMD7 
lokusunda 252 alleli, VVMD7 lokusunda 185 alleli, M3 genotipinde ise VVMD27 lokusunda 185 alleli olarak tespit edilmiştir. Allel verileri indelendiğinde VVMD5 ve VVMD27 lokuslarında hem Boğazkere hem de 1103 P ebeveyninde diploid allel profili gösterirken M2 genotipi söz konusu lokuslarda triploid allel profili göstermiştir. Yine Karadimrit ve $140 \mathrm{Ru}$ ebeveynleri VVMD27 lokusu diploid allel profili gösterirken hem M3 genotipi hem de M4 genotipi söz konusu lokusta triploid allel profili göstermiştir. 1103 P ebeveyninde ZAG79 lokusunda görülen 250 allellin F1 genotiplerinde (M1 ve M2) görülmediği, benzer şekilde $140 \mathrm{Ru}$ ebeveyninde VVMD27 lokusunda 191 allelinin ve ZAG79 lokusunda 260 allelin F1 genotiplerinde (M3 ve M4) görülmediği tespit edilmiştir.

Söz konusu allellerin sonucunda F1 genotiplerinin melezleme aşamalarının doğru yapıldığı ve ana ve baba özelliklerini taşıdığı görülmektedir.

Çizelge 2. F1 genotipleri SSR lokuslarında ebeveynlere ait allelerin karşılaştırılması.

\begin{tabular}{|c|c|c|c|c|c|c|c|c|c|c|c|c|}
\hline No & \multicolumn{2}{|c|}{ VVS2 } & \multicolumn{2}{|c|}{ VVMD5 } & \multicolumn{2}{|c|}{ VVMD7 } & \multicolumn{2}{|c|}{ VVMD27 } & \multicolumn{2}{|c|}{ ZAG79 } & \multicolumn{2}{|c|}{ ZAG62 } \\
\hline Boğazkere & 137 & 147 & 233 & 235 & 232 & $\begin{array}{l}248 \\
256\end{array}$ & 193 & 207 & 246 & 260 & 192 & $\begin{array}{l}202 \\
212\end{array}$ \\
\hline $1103 P$ & 135 & 147 & 233 & 233 & 232 & 254 & 203 & 207 & 250 & 260 & 194 & 212 \\
\hline $\begin{array}{l}\text { M1(Boğazkere } \\
\text { X 1103P-2008) }\end{array}$ & 137 & 147 & 233 & 233 & 232 & $\begin{array}{l}248 \\
254\end{array}$ & 179 & $\begin{array}{l}193 \\
207\end{array}$ & 246 & 260 & 192 & $\begin{array}{l}202 \\
212\end{array}$ \\
\hline $\begin{array}{l}\text { M2(Boğazkere } \\
\text { X 1103P-2009) }\end{array}$ & 135 & 147 & 229 & $\begin{array}{l}233 \\
235\end{array}$ & 232 & $\begin{array}{l}246 \\
252\end{array}$ & 177 & $\begin{array}{l}193 \\
203\end{array}$ & 246 & 260 & 192 & $\begin{array}{l}202 \\
212\end{array}$ \\
\hline Karadimrit & 137 & 149 & 233 & 237 & $\begin{array}{l}230 \\
242\end{array}$ & $\begin{array}{l}238 \\
260\end{array}$ & 189 & 207 & 242 & $\begin{array}{l}250 \\
262\end{array}$ & $\begin{array}{l}194 \\
198\end{array}$ & $\begin{array}{l}202 \\
208\end{array}$ \\
\hline $140 R u$ & 137 & 149 & 233 & 233 & 230 & 260 & 191 & 207 & 250 & 260 & 194 & 208 \\
\hline $\begin{array}{l}\text { M3(Dimrit X } \\
\text { 140Ru-2008) }\end{array}$ & 137 & 149 & 233 & 237 & $\begin{array}{l}230 \\
238\end{array}$ & $\begin{array}{l}242 \\
260\end{array}$ & 185 & $\begin{array}{l}189 \\
207\end{array}$ & 242 & $\begin{array}{l}250 \\
262\end{array}$ & $\begin{array}{l}194 \\
198\end{array}$ & $\begin{array}{l}202 \\
208\end{array}$ \\
\hline $\begin{array}{l}\text { M4(Dimrit X1 } \\
\text { 40Ru-2009) }\end{array}$ & 137 & 149 & 233 & 237 & 230 & $\begin{array}{l}238 \\
260\end{array}$ & 189 & 207 & 242 & $\begin{array}{l}250 \\
262\end{array}$ & $\begin{array}{l}194 \\
198\end{array}$ & $\begin{array}{l}202 \\
208\end{array}$ \\
\hline
\end{tabular}

\section{Sonuç ve Öneriler}

Araştırmamızda denemeye alınan genotipleri DNA izolasyonunda Lodhi vd (1994) metodunun kullanılmasının nedeni; asmalarda yapılan birçok çalışmada kullanılması (Ergül, 2000, Ergül ve Ağaoğlu, 2001) ve diğer izolasyon yöntemlerine göre daha fazla DNA'nın elde edilmesi için genotiplere göre değişkenlik göstermekle beraber daha saf DNA'lar elde edilmesidir.

Primerlerin seçiminde, Avrupa Birliği Araştırma Projesince (GENRES 081), asma çeşit koleksiyonları için kullanılan ve artık tüm dünya tarafından minimum standart set (core set) olarak kabul gören VVMD27, VrZAG79, VrZAG62. VVMD5, VVS2, ve VVMD7 mikrosatelik lokusları olmak üzere toplam 6 SSR primeri kullanılmıştır.

Ebeveynler ve F1'ler lokuslar bazında incelendiğinde, gerek M1 ve M2, gerekse M3 ve M4 genotipleri anne ve babadan ortak allellere sahip olmakla birlikte, ebeveynlerde bulunmayan allellere de sahip oldukları görülmüştür.

Söz konusu allellerin sonucunda F1 genotiplerinin melezleme aşamalarının doğru yapıldığı ve ana ve baba özelliklerini taşıdığı görülmektedir.

Kuraklık, küresel ısınma ile birlikte önümüzdeki çeyrek yüzyılda etkisini çok daha belirgin bir şekilde hissettirecektir. Dolayısıyla kuraklığa ve diğer abiyotik stres koşullarına toleranslı olan bitki popülasyonlarının önemi giderek artmaktadır. Abiyotik strese toleranslı bireylerin elde edilebilmesine yönelik olarak çalışmaların arttırılması gerekmektedir. Konu ile ilgili melezleme programı için oluşturulacak F1 populasyonları doğru ebeveyn, doğru strateji ve doğru melezleme uygulaması ile programlanmalıdır. Söz konusu bu unsurların doğruluğunun teyit edilebilmesi klasik melezleme yönteminde uzun zaman alabilmektedir. SSR analizi ile F1'lerin ebeveynleri ile olan benzerlikleri kısa sürede belirlenerek ön selektif aşaması kısa sürede sonuçlandırılabilmektedir.

Yapılmış olan bu çalışma sonucunda elde edilen veriler ışığında melezleme çalışmaları ile daha üstün özelliklere sahip yeni genotiplerin elde edilmesi, geliştirilmesi ve ümitvar tiplerin seçilmesi çalışmalarına ışık tutabilecek niteliktedir.

¥: Bu çalışma Atilla Çakırın doktora tezinden üretilmiştir.

\section{Kaynaklar}

Adams, L.T. 1979. A Practical Ampelography Grapevine Identification. ISBN: 0-8014-12404, Cornell Univ. USA, $245 \mathrm{p}$.

Ağaoğlu, Y.S. 1999. Bilimsel ve Uygulamalı Bağcılık (Asma Biyolojisi). Kavaklıdere Eğitim Yayınları, No: 1, Ankara. 205 s. 
Ağaoğlu, Y. S., Marasalı, B., Ergül, A. 1998. Asma ıslahında son gelişmeler. IV. Bağcılık Sempozyumu, 20-23 Ekim, Yalova, s. 9-16.

Ağaoğlu, Y. S., Söylemezoğlu, G., Ergül, A., Çalışkan, M. 1995. Ülkemizde yetiştirilen bazı sofralık üzüm çeşitlerinin izoenzim bantlarından yararlanılarak elektroforez tekniği ile tanımlanmaları. Türkiye II. Bahçe Bitkileri Ulusal Kongresi. Cilt II, 3-6 Ekim, Adana, s. 567-571.

Anonim 1990b. Standart Üzüm Çeşitleri Kataloğu. T.C. Tarım ve Köyişleri Bakanlığı, Mesleki Yayınlar Serisi, 15. Ankara. $91 \mathrm{~s}$.

Anonim, 2007. Tekirdağ Bağcılık Araştırma Enstitüsü (Yazılı Görüşme).

Aras, Ö. 2006. Üzüm ve Üzüm Ürünlerinin Toplam Karbonhidrat, Protein, Mineral Madde ve Fenolojik Bileşik İçeriklerinin Belirlenmesi (Yüksek Lisans Tezi). Süleyman Demirel Üniversitesi, Fen Bilimleri Enstitüsü, Bahçe Bitkileri A.B.D., $58 \mathrm{~s}$.

Arroyo-Garcia, R., Ruiz-Garcia, L., Boulling, L., Ocete, R., López, M.A., Arnold, C., Ergul, A., Söylemezoğlu, G., Uzun, H. İ., Cabello, F, Ibáñez, J., Aradhya, M.K., Atanassov, A., Atanassov, I., Balint, S., Cenis, J.L., Costantini, L., Gorislavets, S., Grando, M.S., Klein, B. Y., McGovern, P., Merdinoglu, D., Pejic, I., Pelsy, F., Primikirios, N., Risovannaya, V., Roubelakis-Angelakis, K.A., Snouss, H., Sotiri, P., Tamhankar, S., This, P., Troshin, L., Malpica, J.M., Lefort, F., Martinez-Zapater, J.M. 2006. Genetic evidence for the existence of independent domestication events in grapevine. Molecular Ecology, 15(12): 3707-3714.

Brookfield, J.F.Y. 1996. A simple new method for estimating null allele frequency from heterozygote deficiency. Mos. Ecol., 5: 453455.

Bowers, J.E., Dangl, G. ., Vignani, R., Meredith, C.P. 1996. Isolation and characterization of new polymorphic simple sequence repeat loci in grape (Vitis vinifera L.). Genome, 39: 628633.

Çelik, H., Ağaoğlu, Y.S., Fidan, Y., Marasalı, B., Söylemezoğlu, G. 1998. Genel Bağcılık. Sun Fidan A. Ş. Mesleki Kitaplar Serisi: 1, Ankara.

Çelik, S. 1998. Bağcılık (Ampeloji) Cilt I., Anadolu Matbaa Ambalaj San. ve Tic. Ltd. Şti., ISBN. 975-94530-0-2, Tekirdağ. $426 \mathrm{~s}$.

Çelik, S. 2006. Üzüm Çeşit Kataloğu. Sunfidan A.Ş. Mesleki Kitaplar Serisi: 3. $165 \mathrm{s.}$

Ergül, A. 1992. Bağcılıkta Melezleme Islahı. Yüksek Lisans Semineri. Ankara Üniversitesi Fen Bilimleri Enstitüsü Bahçe Bitkileri A.B.D., Ankara, $92 \mathrm{~s}$.
Ergül, A. 2000. Asmalarda (Vitis vinifera L. cv) Genomik DNA Parmak İzi Analizi ile Moleküler Karakterizasyon. Doktora Tezi. Ankara Üniversitesi Fen Bilimleri Enstitüsü Bahçe Bitkileri A.B.D., 86 s.

Ergül, A., Ağaoğlu, Y.S. 2001. Molecular similarity analysis of some grapevine rootstocks from different nursery in Turkey. J. Agric. Sci., 7: 141-143.

Ergül, A., Kazan, K., Aras, S., Çevik, V., Çelik, H., Söylemezoğlu, G. 2006. AFLP analysis of genetic variation within the two economically important grapevine (Vitis vinifera L.) varietal groups. Genome, 49(5): 467-475.

Fidan, Y. 1985. Özel Bağcılık. Ankara Üniversitesi Ziraat Fakültesi Yayınları 930, Ders Kitabı No: 265. $401 \mathrm{~s}$

Lefort, F., Lally, M., Thompson, D., Douglas, G.C. 1998. Morphological traits microsatellite fingerprinting and genetic relatedness of a stand of elite oaks ( $Q$. robur L.) at Tuallynally, Ireland. Silvae Genetica 47: 5-6.

Lodhi, MA., Guang-Ning Ye, Norman, F., Weeden B., Reisch, I. 1994. A simple and efficient method for DNA extraction from grapevine cultivars, Vitis species and Ampelopsis. Plant Molecular Biology Reporter, 12(1): 6-13.

McGovern, P.E. 2003. Ancient Wine: The Search for the Origins of Viticulture. Princeton University Press, Princeto, New Jersey.

Minch, E., Ruiz-Linares, A., Goldstein, D.B., Feldman, M., Cavalli-Sforza, L.L. 1995. Microsat (Version 1.4d): A Computer Program for Calculating Various Statistics on Microsatellite Allele Data. Stanford. California, University of Stanford.

Nei, M. 1987. Molecular Evolutionary Genetics. Columbia University Pres, Newyork. 106-107 p.

Paetkau, D., Calvert, W., Stirling., I., Strobeck, C. 1995. Microsatellite analysis of population structure in Canadian polar bears. Mol. Ecol., 4: 347-354 p.

Sefc, K.M., Regner, F., Turetschek, E., Glössl, J., Steinkellner, H. 1999. Identification of microsatellite sequences in Vitis riparia and their applicability for genotyping of different Vitis species. Genome, 42: 367-373.

Thomas, M.R., Scott, N.S. 1993. Microsatellite repeats in grapevine reveal DNA polymorphisms when analysed as sequencetagged sites (STSs). Theor. Appl. Genet., 86: 985-990.

Wegner, H.W., Sefc., K.M. 1999. IDENTITY 1.0. Centre for Applied Genetics. University of Agricultural Science, Vienna. 